\title{
Low physical activity work-related and other risk factors increased the risk of poor physical fitness in cement workers
}

\author{
Ditha Diana ${ }^{1}$, Bastaman Basuki ${ }^{1}$, Jull Kurniarobbi. ${ }^{2}$ \\ ${ }^{1}$ Department of Community Medicine, Faculty of Medicine, Universitas Indonesia \\ ${ }^{2}$ Department of Sports Medicine, Faculty of Medicine, Universitas Indonesia
}

\begin{abstract}
Abstrak
Tujuan Aktivitas fisik rendah menyebabkan kebugaran jasmani kurang, yang berdampak pada produktivitas. Penelitian ini bertujuan untuk mengetahui pengaruh aktivitas fisik terkait pekerjaan yang rendah dan faktor risiko lainnya terhadap kebugaran jasmani pekerja.

Metode Subjek penelitian yang dilakukan pada bulan bulan Februari 2008 ini adalah pekerja di 15 departemen yang dipilih secara purposif di PT Semen Padang, Sumatera Barat. Tingkat aktivitas fisik diketahui dari kuesioner Panduan Pengalaman Belajar Lapangan I dan Program Integrasi Hipertensi - Lansia Fakultas Kedokteran Universitas Indonesia 2003. Tingkat kebugaran jasmani diukur dengan menggunakan Harvard Step Test.

Hasil Subjek penelitian adalah 937 laki-laki berusia 18-56 tahun. Subjek mempunyai tingkat kebugaran jasmani rendah sebesar 15,9\%. Faktor risiko dominan terhadap kebugaran jasmani rendah adalah aktivitas fisik pekerjaan yang rendah, kebiasaan merokok, tidak berolahraga, hipertensi, diabetes melitus, dan asma. Subjek dengan aktivitas fisik terkait pekerjaan yang rendah dibandingkan subjek dengan aktivitas fisik tinggi mempunyai risiko 10,71 kali untuk kebugaran jasmani kurang [rasio odds suaian (ORa) =10,71; interval kepercayaan $(C I$ 95\% = 4,71 - 24,33)]. Subjek yang tidak berolahraga dibandingkan dengan yang berolahraga mempunyai risiko 6,3 kali untuk kebugaran jasmani kurang (ORa = 6,30; CI 95\% = 3,69-10,75).

Kesimpulan Aktivitas fisik pekerjaan yang rendah, kebiasaan merokok, tidak berolahraga, hipertensi, diabetes melitus, dan asma merupakan faktor dominan terhadap kebugaran jasmani rendah. Oleh karena itu, selain memperlihatkan faktorfaktor berpengaruh tersebut, pekerja dengan tingkat aktivitas fisik rendah perlu melakukan latihan fisik. (Med J Indones. 2009; 18: 203-7)
\end{abstract}

\begin{abstract}
Aim Low physical activity causes poor physical fitness, which leads to low productivity. The objective of this study was to determine the effects of low work-related physical activity and other risk factors on physical fitness.

Methods This study was done in February 2008. Subjects were workers from 15 departments in PT Semen Padang, West Sumatera (Indonesia). Data on physical activities were collected using the questionnaire from the Student Field Work I Guidebook and Hypertension - Geriatric Integrated Program of the Faculty of Medicine, Universitas Indonesia 2003. Physical fitness was measured using the Harvard Step Test.

Results A number of 937 male workers aged 18 - 56 years participated in this study. Poor physical fitness was found in $15.9 \%$ of the subjects. Low work-related physical activity, smoking, lack of exercise, hypertension, diabetes mellitus, and asthma were dominant risk factors related to poor physical fitness. Subjects with low compared to high work-related activity had a ten-fold risk of poor physical fitness [adjusted odds ratio (ORa) $=10.71 ; 95 \%$ confidence interval $(\mathrm{CI})=4.71-24.33$ ]. In term of physical exercise, subjects who had no compared to those who had physical exercise had a six-fold risk of poor physical fitness $(\mathrm{ORa}=6.30 ; 95 \% \mathrm{CI}=3.69-10.75)$.

Conclussion Low work-related physical activities, smoking, lack of exercise, hypertension, diabetes mellitus, and asthma were correlated to poor physical fitness. It is, among others, therefore necessary to implement exercises for workers with poor physical fitness. (Med J Indones. 2009; 18: 203-7)
\end{abstract}

Key words: exercise test, occupational healts, physical fitness

Workers in the cement industry consist of plant workers, miners and administrative staff. All of them must have good physical fitness in order to achieve high productivity. Physical fitness is influenced by several factors, such as the individual characteristics, the type of work, and the working environment. Individual characteristics include gender, age, ethnic group, body mass index, exercise, and smoking., ${ }^{1,2}$ Work factors that influence physical fitness are the level of physical activity and shift work. Other factors influencing physical fitness are the existence of health and fitness programs at the work place. 
Changing life styles, such as the lack of physical activities, have caused non-infectious diseases to rise. The lack of physical activity and low work-related physical activity may cause positive balance energy changes. This increases fat deposits which is manifest in those with low physical fitness, and in turn, this may lead to the rise of non-infectious diseases. ${ }^{3,4}$ The workers in the cement plant were found to have poor physical fitness.

This study aimed to determine the effects of low workrelated physical activity and other risk factors on poor physical fitness.

\section{METHODS}

The subject consisted of male workers of PT Semen Padang, a cement factory located in West Sumatra (Indonesia). These men must have worked for at least one year and have undergone annual health medical check-ups in February 2008.

Data on age, marital status, and education, year of starting work, household-related physical activities, work-related physical activities, exercise, and smoking habits were obtained using a form especially constructed for this study. Physical fitness was determined by Harvard Step Test. The test was performed by the resident general practitioner.

Subjects were considered to have poor physical fitness if the results of the Harvard Step Test were either low or very low. Subjects considered to have good physical fitness are subjects with either moderate, good, or very good results.

Data on work-related activities were collected using the questionnaire from the Student Field Work I Guidebook and Hypertension - Geriatric Integrated Program of the Faculty of Medicine, Universitas Indonesia 2003. ${ }^{5}$
Work-related activities were categorized as low, moderate, and high. High work-related activities were the work done by diggers and laborers; moderate workrelated activities include work by carpenters, dustmen, stonemasons, doing such work as drilling, painting, hand cutting; while low work-related activities were work by the office workers, office custodian, and those doing sewing, typing, instrument panel monitors, etc.

Smoking was expressed by the Brinkman index (nonsmoker/light smoker/moderate/ heavy smoker). Physical exercises were determined for the last six months (no exercise/light exercise/heavy exercise).

Since the prevalence of poor physical fitness in the workers was not high, the risk for poor physical fitness was analyzed by logistic regression, ${ }^{6}$ with Stata version. ${ }^{9}$

Ethical approval for the research was obtained from the Ethical Commission of the Faculty of Medicine, Universitas Indonesia, Jakarta.

\section{RESULTS}

There were 940 potential candidates for this study. However, three subjects did not fill questionnaires, leaving 937 subjects for analysis. The prevalence of poor physical fitness was $15.9 \%$. Subjects with good and poor physical fitness were similarly distributed in terms of age, marital status and education. Subjects with college level education were more likely to be at risk for poor physical fitness compared to those with senior high school level of education (Table 1).

Table 1. Some demographic characteristics and the risk of poor physical fitness

\begin{tabular}{|c|c|c|c|c|c|c|c|}
\hline & \multicolumn{2}{|c|}{$\begin{array}{c}\text { Good physical } \\
\text { fitness } \\
(\mathrm{n}=788) \\
\end{array}$} & \multicolumn{2}{|c|}{$\begin{array}{c}\text { Poor physical } \\
\text { fitness } \\
(\mathrm{n}=149) \\
\end{array}$} & \multirow{2}{*}{$\begin{array}{l}\text { Crude } \\
\text { odds } \\
\text { ratio }\end{array}$} & \multirow[t]{2}{*}{$\begin{array}{c}95 \% \\
\text { Confidence } \\
\text { Interval }\end{array}$} & \multirow[t]{2}{*}{$\mathrm{p}$} \\
\hline & $\mathrm{n}$ & $\%$ & $\mathrm{n}$ & $\%$ & & & \\
\hline \multicolumn{8}{|l|}{ Age } \\
\hline $18-30$ years & 49 & 6.2 & 8 & 5.4 & 1.00 & Reference & \\
\hline $31-40$ years & 222 & 28.2 & 45 & 30.2 & 1.24 & $0.55-2.80$ & 0.602 \\
\hline $41-56$ years & 517 & 65.6 & 96 & 64.4 & 1.14 & $0.52-2.48$ & 0.746 \\
\hline \multicolumn{8}{|l|}{ Marital status } \\
\hline Unmarried & 34 & 4.3 & 9 & 6.0 & 1.00 & Reference & \\
\hline Married & 750 & 95.2 & 140 & 94.0 & 0.71 & $0.33-1.50$ & 0.366 \\
\hline Divorced & 4 & 0.5 & 0 & 0.00 & $\mathrm{n} / \mathrm{a}^{*}$ & - & - \\
\hline \multicolumn{8}{|l|}{ Education } \\
\hline Senior High School & 694 & 88.1 & 126 & 84.6 & 1.00 & Reference & \\
\hline College & 51 & 6.5 & 18 & 12.1 & 1.94 & $1.10-3.44$ & 0.022 \\
\hline University & 43 & 5.4 & 5 & 3.3 & 0.64 & $0.25-1.64$ & 0.356 \\
\hline \multicolumn{8}{|l|}{ Length of work } \\
\hline$<10$ years & 186 & 23.6 & 43 & 28.9 & 1.00 & Reference & \\
\hline $11-20$ years & 212 & 26.9 & 28 & 18.8 & 0.57 & $0.34-0.96$ & 0.033 \\
\hline$>20$ years & 390 & 49.5 & 78 & 52.3 & 0.87 & $0.57-1.31$ & 0.490 \\
\hline
\end{tabular}


Table 2 showed that subjects with good and poor physical fitness were similarly distributed with respect to household-related physical activities, body mass index, and history of kidney diseases.

In the final model (Table 3), exercise, smoking, a history of hypertension, diabetes mellitus, and asthma were found to be the dominant risk factors related to poor physical fitness.

Subjects with moderate work-related activities had a fourfold risk to be of poor physical fitness compared to those with high work-related physical activities. Those with low work-related activities had a ten-fold risk to be of poor physical fitness. Furthermore, in terms of exercise, subjects lacking exercise had a six-fold higher risk to be of poor physical fitness. However, no relationship was found between light smokers to poor physical fitness.

Nevertheless, subjects who were heavy smokers tend to have a higher risk for poor physical fitness compared to nonsmokers and moderate smokers. Moderate smokers were four times at risk, while heavy smokers were nine times at risk for poor physical fitness.

Table 2. Household-related physical activities, body mass index and kidney disease and the risk of poor physical fitness

\begin{tabular}{|c|c|c|c|c|c|c|c|}
\hline & \multicolumn{2}{|c|}{$\begin{array}{c}\text { Good physical } \\
\text { fitness } \\
(\mathrm{n}=788)\end{array}$} & \multicolumn{2}{|c|}{$\begin{array}{c}\text { Poor physical } \\
\text { fitness } \\
(\mathrm{n}=149)\end{array}$} & \multirow{2}{*}{$\begin{array}{l}\text { Crude } \\
\text { odds } \\
\text { ratio }\end{array}$} & \multirow{2}{*}{$\begin{array}{c}95 \% \\
\text { Confidence } \\
\text { Interval }\end{array}$} & \multirow[t]{2}{*}{$\mathrm{P}$} \\
\hline & $\mathrm{n}$ & $\%$ & $\mathrm{n}$ & $\%$ & & & \\
\hline \multicolumn{8}{|c|}{$\begin{array}{l}\text { Household-related physical } \\
\text { activities }\end{array}$} \\
\hline Moderate & 14 & 1.8 & 2 & 1.3 & 1.00 & Reference & \\
\hline Low & 774 & 98.2 & 147 & 98.7 & 1.33 & $0.30-5.91$ & 0.708 \\
\hline \multicolumn{8}{|c|}{ Body Mass Index } \\
\hline Normal & 427 & 54.2 & 81 & 54.4 & 1.00 & Reference & \\
\hline Underweight & 22 & 2.8 & 7 & 4.7 & 1.68 & $0.69-4.06$ & 0.251 \\
\hline Poor & 5 & 0.6 & 1 & 0.7 & 1.05 & $0.12-9.14$ & 0.962 \\
\hline Overweight & 161 & 20.4 & 27 & 18.1 & 0.88 & $0.55-1.42$ & 0.609 \\
\hline Obese & 173 & 22.0 & 33 & 22.1 & 1.01 & $0.65-1.56$ & 0.980 \\
\hline \multicolumn{8}{|c|}{ Kidney disease } \\
\hline No & 776 & 98.5 & 146 & 98.0 & 1.00 & Reference & \\
\hline Yes & 12 & 1.5 & 3 & $2 ., 0$ & 1.15 & $0.61-2.18$ & 0.663 \\
\hline
\end{tabular}

Table 3. The relationship between work-related physical activity, exercise, smoking, hypertension, diabetes mellitus and asthma and the risk of poor physical fitness

\begin{tabular}{|c|c|c|c|c|c|c|c|}
\hline & \multicolumn{2}{|c|}{$\begin{array}{c}\text { Good physical } \\
\text { fitness } \\
(\mathrm{n}=788) \\
\end{array}$} & \multicolumn{2}{|c|}{$\begin{array}{c}\text { Poor physical } \\
\text { fitness } \\
(\mathrm{n}=149) \\
\end{array}$} & \multirow[t]{2}{*}{$\begin{array}{l}\text { Adjusted } \\
\text { odds ratio }\end{array}$} & \multirow{2}{*}{$\begin{array}{c}95 \% \\
\text { Confidence } \\
\text { Interval }\end{array}$} & \multirow[t]{2}{*}{$\mathrm{P}$} \\
\hline & $\mathrm{n}$ & $\%$ & $\mathrm{n}$ & $\%$ & & & \\
\hline \multicolumn{8}{|c|}{$\begin{array}{l}\text { Work-related physical } \\
\text { activities }\end{array}$} \\
\hline High & 523 & 66.4 & 41 & 27.5 & 1.00 & Reference & \\
\hline Moderate & 143 & 18.1 & 48 & 32.2 & 3.96 & $2.32-6.77$ & 0.000 \\
\hline Low & 122 & 15.5 & 60 & 40.3 & 10.71 & $4.71-24.33$ & 0.000 \\
\hline \multicolumn{8}{|l|}{ Exercise } \\
\hline Yes & 396 & 50.3 & 19 & 12.7 & 1.00 & Reference & \\
\hline No & 392 & 49.7 & 130 & 87.3 & 6.30 & $3.69-10.75$ & 0.000 \\
\hline \multicolumn{8}{|l|}{ Smoking } \\
\hline Non-smoker & 120 & 15.2 & 7 & 4.7 & 1.00 & Reference & \\
\hline Light smoker & 449 & 57.0 & 34 & 22.8 & 0.86 & $0.35-2.14$ & 0.753 \\
\hline Moderate smoker & 176 & 22.3 & 62 & 41.6 & 3.74 & $1.54-9.08$ & 0.004 \\
\hline Heavy smoker & 43 & 5.5 & 46 & 30.9 & 9.23 & $3.60-23.67$ & 0.000 \\
\hline \multicolumn{8}{|l|}{ Hypertension } \\
\hline No & 756 & 95.9 & 131 & 87.9 & 1.00 & Reference & \\
\hline Yes & 32 & 4.1 & 18 & 12.1 & 2.33 & $1.04-5.20$ & 0.038 \\
\hline \multicolumn{8}{|l|}{ Diabetes mellitus } \\
\hline No & 766 & 97.2 & 136 & 91.3 & 1.00 & Reference & \\
\hline Yes & 22 & 2.8 & 13 & 8.7 & 2.96 & $1.10-7.94$ & 0.031 \\
\hline \multicolumn{8}{|l|}{ Asthma } \\
\hline No & 787 & 99.9 & 143 & 96.0 & 1.00 & Reference & \\
\hline Yes & 1 & 0.1 & 6 & 4.0 & 7.47 & $0.42-132.48$ & 0.171 \\
\hline
\end{tabular}




\section{DISCUSSION}

There were several limitations in this study. Firstly, there may be information bias originating from interviewing techniques. The interviewers may have prior knowledge about the dependent variable, the effects of physical fitness. They might also fit the subject's answers to their own knowledge. To reduce the bias, the interviewers were trained using the questionnaires. Secondly, there may be recall bias since assessment of physical activities was conducted with an interview using questionnaires, which relied on the subjects' memories. To minimize recall bias, examples were given to the subjects during the interview.

On the positive side, this study had a fairly large sample. Only 3 out of 940 candidates dropped out of the study. Interviews and examinations were conducted by resident medical doctors with sufficient knowledge about the study.

Poor physical fitness was found in $15.9 \%$ of the subjects. This compares with a previous study, where the prevalence among adults is $13.9 \% .{ }^{7}$ Other studies among employees in South Sumatra, Jakarta, West Java, and Bali in 2002 however found the prevalence of poor physical fitness to be higher $(72.5 \% \text {. })^{8}$

The final model showed that subjects with moderate work-related physical activities had almost four times $(\mathrm{OR}=3.96 ; \mathrm{p}=0.000)$ the risk of poor physical fitness, while those with low work-related physical activities had 10.7 times the risk of poor physical fitness $(\mathrm{OR}=10.71 ; \mathrm{p}=0.000)$ compared to those with high physical activities. This result showed a strong relationship between work-related physical activities and poor physical fitness.

Several studies have shown the correlation between physical activity and physical fitness. A previous study among young workers in northern Finland showed that workers with heavy physical activities have better physical fitness compared to workers with light physical activities. ${ }^{9}$

A survey in the United States reported that in 2004, 24\% young adult Americans (less than 18 years old) had only light physical activities. ${ }^{10}$ Another study among 9,824 adult men (aged $35-79$ years old) in Puerto Rico found that the risk of heart disease increases $34 \%$ in subjects with light physical activities. ${ }^{11}$

This study did not find a correlation between light smoking and physical fitness. On the other hand, mod- erate and heavy smokers had a higher risk of poor physical fitness compared to nonsmokers. This was similar to the results of previous studies among employees in South Sumatra, Jakarta, West Java, and Bali in 2002, which also showed that smoking, increased the risk of poor physical fitness by about $74 \% .^{12}$

A history of hypertension also increased the risk of poor physical fitness. This finding was similar with previous studies. ${ }^{13,14}$

A history of diabetes mellitus increased the risk of poor physical fitness. This was similar with previous studies on the correlation between glucose intolerance and physical activity to low habitual energy expenditure and physical fitness. The study was conducted in the United Kingdom with 775 subjects aged 45-70 years. A negative correlation was found between high blood glucose level and physical fitness $(\mathrm{P}<0.01$ in men and $\mathrm{P}<0.001$ in women). ${ }^{15}$

Finally, this study showed that a history of asthma moderately $(\mathrm{P}=0.171)$ increased the risk of poor physical fitness. A multivariable assessment of the 6-min walking test among 53 patients with chronic obstructive pulmonary disease in Holland found that 29 of them can do a short distance walking test $(\mathrm{P}=0.005) .{ }^{16}$

In conclusion, work-related physical activities, smoking, exercise, hypertension, diabetes mellitus, and asthma were correlated to poor physical fitness. It is therefore necessary to prevent poor physical fitness by implementing exercises.

\section{Acknowledgments}

The authors would like to thank all the subjects who willingly participated in this study. We would also like to express our appreciation to PT Semen Padang in West Sumatera for facilitating this study.

\section{REFERENCES}

1. Departemen Kesehatan Republik Indonesia. Petunjuk teknis kebugaran jasmani. Jakarta: The Department; 2005.

2. Panduan kesehatan olahraga bagi petugas kesehatan. [Revised 2007 Jun 14; cited 2008 Sep 18]. Available from: http://www.depkes.go.id/download/Panduan20\% Keseha$\tan \% 20$ Olahraga.pdf.

3. Locke CT, Ainsworth. The relationship between pedometer-determined ambulatory activity and body composition variables. [revised: 2002 Jan 05; cited 2007 Jun 30]. Available from: http://www.nature.com/ijo/journal/v31/ 
4. Aimet M, Pokan R, Kotzian S. Poster abstract strength/balance training in chronic disease. [revised 2004 Dec 08; cited 2007 Jul 5]. Available from: http://www.openarchives.org/OAI/2.0/

5. Faculty of Medicine Universitas Indonesia. Panduan Pengalaman Belajar Lapangan I dan Program Integrasi Hipertensi - Lansia. Jakarta: The Faculty; 2003.

6. Barros AJD, Hirakata VN. Alternative for logistic regression in cross-sectional studies: an empirical comparison that directly estimates the prevalence ratio. BMC Medical Research Methodology [serial online]. [revised 2003 Oct; cited 2007 Aug 1]; 3 (21): [13 p]. Available from : http:// www.biomedcentral.com/1471-22993/3/21.

7. Palmieri M, Perdomo R. Lack of physical activity more life threatening than obesity. Small amounts of physical activity found to be protective. [revised 2008 Apr 14; cited 2008 May 28]. Available from: http://www.seniorjournal.com

8. Kusmana D. Jakarta cardiovascular study. The city that promotes Indonesian healthy heart. Proceedings of the 1st Jakarta Cardiovascular Conference: 2008 March 23, Jakarta, Indonesia; 2008

9. Ridjab DA. Modifikasi gaya hidup dan tekanan darah. Maj Kedok Indones. 2007;53:159-65.

10. Calton BA, Solomon RZS, Moore SC, Schatzkin A, Schairer C, Albamas D, et al. A prospective study of physical activity and the risk of pancreatic cancer among women (United States). [revised 2008 Feb 28; cited 2008 May 28]. Available from: http://www.biomedcentral.com
11. Carnethon MR, Gulati M, Greenland P. Prevalence and cardiovascular disease correlates of low cardio respiratory fitness in adolescents and adults. [revised 2005 Des 21; cited 2008 Apr 28]. Available from: http://jama.ama-assn.org/cgi/

12. Departemen Kesehatan Republik Indonesia. Hasil survey kebugaran jasmani di provinsi Sumatera Selatan, DKI Jakarta, Jawa Barat dan Bali Tahun 2002. Jakarta: The Department; 2004.

13. Boreham CA, Ferreira I, Twisk JW, Gallager AM, Savage MJ, Murray LJ. Cardio respiratory fitness, physical activity and arterial stiffness. [revised 2004 Sep 27; cited 2008 May 31]. Available from: http://hyper.ahajournal.org/cgi/ content/full/44/5/721

14. Armstrong K, Rakhit D, Jeffriess L, Johnson D, Leano R, Prins J, et al. Cardio respiratory fitness is related to physical inactivity, metabolic risk factors and atherosclerotic burden in glucose-intolerant renal transplant recipients. [revised 2006 Oct 4; cited 2008 Jun 1]. Available from: http://cjasn. asnjournal.org/cgi/content/full/1/6/1275

15. Wareham NJ, Wong MY, Day NE. Glucose intolerance and physical inactivity: the relative importance of low habitual energy expenditure and cardiorespiratory fitness. [revised 2000 Oct 12; cited 2008 Jun 1]. Available from: http://ajeoxfordjournals.org/cgi/content/full/152/2/132

16. Stel HF, Bogarard JM, Nouwens LHMR, Colland VT. Multivariable assessment of the 6-min walking test in patients with chronic obstructive pulmonary disease. [revised 2001 Jun 7; cited 2008 Jun 1]. Available from: http://ajrccm. atsjournals.org/cgi/content/full/163/7/1567 